\title{
RECENT LEGISLATIVE AND JUDICIAL TRENDS IN CONSUMER CREDIT IN CANADA
}

\author{
JACOB S. ZIEGEL*
}

The use of consumer credit on a large scale has become very widespread in Canada since World War II. Until recently there was only a small body of legislative and judicial law for the protection of the consumer in his dealings with credit grantors. However, this decade has seen the enactment of a large number of statutes for the protection of the consumer in his credit dealings. The writer analyses these new statutes as well as some of the recent judicial decisions in the field.

\section{I-INTRODUCTION}

There has been a phenomenal increase in the use of consumer credit in Canada since the end of the Second World War. In 1948 the balance outstanding on all forms of consumer credit was $\$ 835 \mathrm{~m} .{ }^{1}$ at the end of 1967 it was not less than $\$ 8,324 \mathrm{~m}^{2}{ }^{2}$-an almost tenfold increase over the 1948 figure. The 1967 end of year balance represents approximately 20 per cent of the net personal disposable income of all Canadians as compared to 7.5 per cent for $1948 .^{3}$ In other words, the growth of consumer credit has been three times as rapid as the growth in personal incomes.

Table 1 shows the composition of the 1967 figure, the different types of credit grantors, and the different forms of consumer credit. Here too there have been some dramatic changes. Historically, vendor's credit -that is, credit supplied by retailers at the time of sale-has been the oldest form of consumer credit in Canada and until the end of the war usually took the form of an instalment sale secured by a conditional sale agreement. Since most retailers, with the exception of department stores, do not usually carry their own paper, the practice is for them to sell the paper to one of the $\mathbf{1 5 0}$ or so sales finance companies that are estimated to operate in Canada. During the past decade there has been a pronounced shift in favour of charge accounts or "open-ended" lines of credit and they now account for the bulk of the credit advanced by the department stores.

If the consumer prefers, he can borrow the money from a credit union, small loans company, bank or, less frequently, his life insurance company and pay cash for his purchase or use the loan for some other purpose. The striking change that has occurred here is in relation to the banks. In 1948 only $\$ 154 \mathrm{~m}$. was owing to the banks in the form of "unsecured" personal loans." At the end of 1967 the figure was $\$ 2,977,{ }^{5}$ and as Table 1 shows the banks are now easily the largest source of consumer credit and account for approximately $36 \%{ }^{6}$ of the

- LL.M., Ph.D. (U. of London); of Lincoln's Inn and the B.C. Bar. Professor, Faculty of Law, McGill University. The material in this article was originally presented by the writer to the Second Annual Law Refresher Course of the Law Society of Alberta at Banff, Alberta, on May 8, 1969.

1 Bank of Canada, Statistical Summary, 1966 Supplement 112-3.

2 Bank of Canada, Statistical Summary, March, 1969, 180, 210, 211.

3 Canadian Statistical Review, June 1968, 5, Table 11; Neufeld, "The Economic Significance of Consumer Credit" in Consumer Credit in Canada 13, Table II (Ziegel \& Olley, eds., 1966). "Personal Disposable Income" means total of personal income less personal direct taxes. Id.

4 Bank of Canada, Statistical Summary, 1964 Supplement 98-101.

B Bank of Canada, Statistical Summary. March 1969, 210.

B Total consumer credit $(\$ 8,324 \mathrm{~m}$.) divided into Chartered Bank Personal Unsecured Loans $(\$ 2,977 \mathrm{~m}$.). See Table 1, below, for detalls. 
total. Their massive penetration of the market is explained in part by changes in the Bank Act ${ }^{8}$ which have encouraged the granting of consumer loans and, more importantly, by the belated realization on the part of the banks that consumer credit is safe and profitable business. The rates charged by the banks are lower than those of its competitors, with the exception of credit unions and life insurance companies, and this fact has had a very marked impact on the volume of business transacted by the sales finance companies. During the past year the banks, acting singly or in combination, have also introduced various types of open-ended lines of credit, and this may be expected to increase still further their slice of the market.

BALANCES OUTSTANDING AT THE END OF 1967: CONSUMER CREDIT IN CANADA* SELECTED HOLDERS ${ }^{7}$

Sales Finance Companies ${ }^{1}$

Consumer Loan Companies: ${ }^{2}$

instalment credit

cash loans

Chartered Bank Personal Unsecured Loans ${ }^{3}$

Quebec Savings Banks Unsecured Loans

Life Insurance Companies Policy Loans 486

Department Stores

Furniture \& Appliance Dealers:

instalment credit

Motor Vehicle Dealers Instalment Credit

Other Retail Dealers

* Credit extended mainly to individuals; includes unidentifiable amounts of credit extended for non-consumer purposes; excludes certain forms of credit for which no statistics are available.

1. The figures shown represent the instalment loan balances outstanding on retail purchases of consumer goods financed under conditional sale agreements by sales finance and consumer loan companies. The sales finance companies extend a small amount of cash loans but monthly data on cash loans is available only for the consumer loan companies.

2. Companies licensed under the Small Loans Act and affiliated companies engaged in making personal loans.

3. "Unsecured loans" means loans not secured by marketable stocks and bonds.

\section{II.-THE CONSTITUTIONAL POSITION}

So much by way of background. Next a few words about the apportionment of legislative powers between the federal and provincial governments in questions concerning consumer credit. The honours are 
fairly evenly divided. The provinces possess a general jurisdiction over questions involving property and civil rights, ${ }^{9}$ but this power is subject to the exelusive federal jurisdiction over such specific areas as banks and banking, ${ }^{10}$ promissory notes and bills of exchange, ${ }^{11}$ interest, ${ }^{12}$ and bankruptcy and insolvency. ${ }^{13}$ The criminal law ${ }^{14}$ and the regulation of trade and commerce ${ }^{15}$ also fall within the federal jurisdiction, but the latter head of power has so far been given nothing like the generous interpretation which it enjoys in the United States. In the constitutional setting "interest" has generally been assumed to relate to the cost of a loan or the consideration for forbearing to sue on a debt, and if this assumption is correct the federal government would appear to lack power to regulate the cost of vendors' credit. In other areas of consumer credit, too, the precise scope of the power of the two levels of government has often been far from clear. Understandably credit grantors subject to provincial jurisdiction have objected to regulatory legislation, such as disclosure requirements, which did not apply equally to their principal competitors, the banks, who fall under federal jurisdiction. In an effort to resolve some of the difficulties a number of federal-provincial conferences have been held during the past two years, and although they have undoubtedly served a most useful purpose they have not so far led either to exactly parallel or, where appropriate, complementary legislation at the two levels of government.

\section{III.-THE EARLY HISTORY OF CONSUMER CREDIT REGULATION}

Canada's history of consumer credit regulation is as old as most countries' and, at the provincial level, goes back ar far as 1889. By 1939 all the provinces had some type of regulation, although it was generally very modest in character. In keeping with the then prevailing form of consumer credit it was usually confined to the regulation of some aspects of conditional sales and involved a limited form of assimilation of this device to the chattel mortgage: thus the buyer was given an equity of redemption and a right to be notified of any intended resale of the goods after they had beeen repossessed by the seller. The Prairie Provinces, spurred by the exigencies of the depression, engaged in much more venturesome legislation which severely restricted creditors' remedies in a variety of ways. It has survived to this day and has influenced the post-war legislation of several of the other provinces. The only pre-war federal legislation of any consequence was the Small Loans Act of 1939. ${ }^{18}$ This was based on the sixth draft of the American Uniform Small Loan Law $^{17}$ but differed from it in a number of important respects.

\section{IV.-POST-WAR DEVELOPIMENTS}

More legislation has been adopted in the past five years than in the preceding sixty years. All the provinces with the exception of one

9 British North America Act 1867, 30-31 Vict., c. 3, s. 92 (13).

10 B.N.A. Act, s. 91 . (15).

11 B.N.A. Act, s. 91 (18)

12 B.N.A. Act, s. 91 (19)

13 B.N.A. Act, s. 91 (21):

14 B.N.A. Act, s. 91 (27).

15 B.N.A. Act, s. 91 (2).

16 S.C. 1939 , c. 23 ; now R.S.C. 1952, c. 251 ; amended S.C. 1956, c. 46.

17 Reprinted in Hubachek, Annotations on Small Loan Laws 181-209 (1938). 
(Quebec) have shared in this orgy. Some provinces now have five or more Acts which deal with different facets of consumer credit. The federal government has also contributed its still inadequate quota of legislation and has established a Department of Consumer and Corporate Affairs-one of the first in the Western world. It is obvious then that Canada is ready for a comprehensive code of consumer credit legislation comparable to the effort which culminated last year in the adoption by the American Uniformity Commissioners of the Uniform Consumer Credit Code. ${ }^{18}$ Manitoba has actually prepared the first draft of such an Act ${ }^{18 a}$ So far, however, our Uniformity Commissioners have taken little interest in the subject. Presumably this is because it is felt that adequate machinery has already been established for consultation among the federal and provincial officials concerned with the administration of the recently enacted legislation.

What accounts for this spate of legislative activity? One reason is undoubtedly the enormous growth of consumer credit in the post-war period and public awareness of its central role in the social and economic life of the nation. Another is due to recurring complaints about certain types of abuses and the concern expressed especially by social welfare agencies about the plight of the over-committeed debtor. A third cause is directly attributable to the recommendations of various committees of enquiry, of whom there have been at least six. Finally, there is the imitative tendency among the provinces whose influence should never be underestimated, and the irresistible urge of politicians to keep their public image brightly burnished.

\section{V.-ANALYSIS OF RECENT LEGISLATION AND SOME OUTSTANDING PROBLEMS}

It is not possible to comment on all the issues dealt with in the recent legislation, and the author's remarks will be confined to some of the more important problems.

\section{Regulation of Door to Door Sales.}

Door to door sales only account for about 1 per cent of all retail sales, but they attract a disproportionate number of complaints. A recent survey of 250 families in Hamilton, Ontario, ${ }^{19}$ showed that a large majority had been approached at some time or other by itinerant salesmen and a high percentage of the respondents had some complaint about the goods or services purchased by them. High pressure sales tactics and serious misrepresentations about the nature of the goods or services offered or the contents of the contract signed by the householder are among the most common complaints. Equally objectionable is the device known as "referral sale" which has been widely employed.

In the United Kingdom regulatory legislation was first recommended in the 1962 Report of the (Molony) Committee on Consumer Protection, ${ }^{20}$ and these recommendations were implemented by the British

\footnotetext{
18 C.C.H. Instalment Credit Guide, No. 183, August 19, 1968. (A revised Code is in the course of preparation)

ina See now The Consumer Protection Act, 1st Sess. 29th Man. Leg. (1969), Bill 12.

19 The Survey was conducted by the Canadian Welfare Councll and will be published under the title of "The Incidence of Debt and the Need for Debt Counselling in Low-Income Families". The writer acted as legal consultant.

20 Final Report of the Committee on Consumer Protection, 1962, Cmnd. 1781.
} 
government in the Hire-Purchase Act of 1964. ${ }^{21}$ The British legislation won quick support in Canada. Saskatchewan adopted similar legislation in $1965,,^{22}$ and since then almost all the other provinces have followed suit. A common feature of all the legislation is that it provides for a "cooling off" period-four days in Alberta's case ${ }^{23}$-following the delivery of a copy of the agreement to the buyer during which he may cancel the agreement. The purpose of this provision is to neutralize the undesirable effects of high pressure salesmanship, but unfortunately it does not per se remedy the effects of misrepresentations since these may not come to light until after the cooling off period has expired. The Canadian provisions differ from the English ones in that the Canadian provisions usually also contain requirements concerning the licensing and bonding of itinerant salesmen.

A question that has troubled all the legislative draftsmen concerns the types of agreement to which the new legislation is to apply. It is not easy to devise a formula that will close all the possible loopholes and at the same time exclude transactions that are regarded as normal and unexceptionable. The Alberta provisions illustrate the difficulties. The Act applies to all "sales contracts". ${ }^{24}$ A "sale contract" is extensively defined $^{25}$ as meaning, inter alia, an agreement for the sale of goods or services or both "for future delivery in whole or in part" or an agreement in which the seller retains a security interest in the goods. In other words, the Act would not appear to apply to cash sales accompanied by immediate delivery of the goods or performance of the service, or even to credit sales where the buyer becomes the immediate owner of the goods. The Ontario experience has shown that sellers are quick to exploit these gaps.

Another difficulty arises out of Section $3(2)$. This provides that the Act shall not apply "where the sales contract is solicited, negotiated, or concluded at (a) the seller's or the salesman's normal business premises, or (b) a market place, auction, trade fair, agricultural fair or exhibition." It is easy to see what the draftsman had in mind. He wanted to exclude the type of transaction in which the buyer visits the seller's shop or showroom but signs the actual contract at home. He did not foresee however that some shrewd door-to-door salesman would seize upon this provision by casting his sales pitch at the buyer's residence and then, while the buyer's ardour was still strong, quickly whisk him off to an office conveniently set up in the locality for the purpose of signing the contract. It has actually happened in Ontario!

Section 3(3) also deserves a brief word. It contains some further exceptions, and these include various types of commercial sales, ${ }^{26}$ all

21 Hire-Purchase Act 1964, (1964), c. 53. See now Hire-Purchase Act, 1965, (1965),

22 The Direct Sales Act, S.S. 1965, c. 71.

23 Direct Sales Cancellation Act, S.A. 1966, c. 28, s. 6.

24 Id., s. 3.

25 Id.', S. 2 (e).

(a) to a sales contract made

(i) between a manufacturer or distributor and a wholesaler in respect of goods that the wholesaler intends to resell in the course of his business, or

(ii) between a manufacturer, distributor or wholesaler and a retailer in respect of goods that the retailer intends to resell in the course of his or (b) to a sales contract under which a retailer is the buyer of goods intended

(c) to a sales contract under which the original buyer is a corporation, or ...". 
sales where the buyer is a corporation, mail order sales, and sales of perishable foodstuffs. It will be observed, however, that it is not all commercial sales that are excluded and that a wide variety of nonconsumer buyers, including farmers and all types of professionals, continue to be protected by the Act unless and until the LieutenantGovernor in Council exercises his exempting powers under Section $3(4) .{ }^{27}$ Some of the other provincial acts are by no means as generous. It is also noteworthy that even very small sales (other than those affecting perishable products or those accompanied by immediate delivery) are caught by the Act.

\section{Disclosure Legislation}

In most consumer credit agreements the finance charge or cost of the loan, as the case may be, constitutes a very significant part of the transaction. Moreover, charges vary considerably between the different types of credit grantors and lenders and sometimes even among members of the same type of agency. For these reasons it is important that the consumer should be told the cost of the credit to him in clear and meaningful terms and in terms that will enable him to compare the cost of the different types of credit grantors, or the rate of return on his own savings with what he is being asked to pay for the use of someone else's money. Until the adoption of the recent legislation there was no way in which the consumer could make this comparison because each type of credit grantor had his own method of disclosing the cost of credit-and sometimes not disclosing it at all.

With the rapid growth of consumer credit in both Canada and the United States the problem assumed serious proportions. Accordingly, from the early sixties onwards efforts were made in both countries to require the cost of the credit to be stated as an annual percentage rate as well as in dollars and cents. Senator Douglas led the fight in the U.S. and in Canada he found a willing partner in Senator Croll. Their efforts were vigorously resisted by many segments of the consumer credit industry on numerous grounds, of which the most important one (but usually the least stressed) was the fear that credit grantors would be branded as usurers if the public realized that their rates were well above the traditional " 6 per cent".

What finally broke the ice in Canada was a succession of reportsthe Porter report on Banking and Finance, ${ }^{28}$ the report of the Select Committee of the Ontario Legislature, ${ }^{29}$ and the Moreira report in Nova Scotia ${ }^{30}$-all of which strongly favoured the percentage disclosure principle. Nova Scotia and Ontario quickly introduced implementing legislation and their example was soon followed by most of the other provinces and by the federal government with respect to bank loans. Canada was slightly ahead of the U.S. in introducing the new legislation. In the first six drafts of the Uniform Consumer Credit Code the Uniformity Commissioners had proposed a different method of disclosure.

27 Direct Sales Cancellation Act, as amended, S.A. 1967, c. 14:

"3 (4) The Lieutenant Governor in Council may make regulations declaring that this Act does not apply to any class or kind of seller of goods or of

28 Report of the Royal Commission on Banking and Finance, 1964.

29 Final Report of the Select Committee of the Ontario Legislature on Consumer Credit, 1965.

30 Report of the Royal Commission on the Cost of Borrowing Money, the Cost of Credit, and Related Matters in the Province of Nova Scotia, Final Report, 1965. 
However, their hands were forced when Congress last year adopted the Consumer Credit Protection Act ${ }^{31}$ with its mandatory annual percentage disclosure provisions.

The Canadian legislation has now been in force for a couple of years, and we are in a better position to assess its effect. So far it appears to have made very little difference-consumers continue to use credit in pretty much the same way as before. Contrary to their fears, credit grantors have not suffered a serious decline of business or indeed any decline. It is true that the banks have captured much of the business that previously went to the sales finance companies and, to a lesser extent, the small loan companies, but this trend was already well under way before the disclosure legislation was adopted. All this is not meant to suggest that the legislation was superfluousfar from it. It does show, I think, that some of its protagonists had exaggerated its benefits just as some of its detractors exaggerated its faults. The truth is that many factors influence the choice of one type of credit grantor rather than another and that the cost of the credit is not always the dominant consideration. This is particularly true in the case of low income consumers.

In Alberta, the disclosure legislation is to be found in the Credit and Loan Agreements Act, ${ }^{32}$ and the important regulations made under the Act. Let us look at some of the salient features of the Act. The Act applies both to credit sales ${ }^{33}$-called "time sale agreement" in the Act-and to loans. ${ }^{34}$ It also applies to "open ended" or revolving forms of agreements, referred to respectively in the Act as "continuous deferred payment"35 plans and "revolving loan agreements"36 and to refinanced ${ }^{37}$ as well as original credit agreements. ${ }^{38}$

The Act also contains some important exemptions. Read literally the Act only applies to the sale of goods, or to a combined sale of goods and services, and not of services alone ${ }^{39}$ but this is probably an oversight. Sales below $\$ 50^{40}$ and sales where the credit charge does not exceed $\$ 10$ and is precomputed ${ }^{41}$ and sales and loans to industrial and commercial enterprises other than those to farm, ranch or feed lot operators $^{42}$ are also excluded. However, as in the case of the direct sellers legislation, it will be observed that many types of non-consumer transactions remain covered. Another important exception encompasses all agreements for the sale of land and loans secured by a mortgage on land. ${ }^{43}$ In view of the widespread abuses in the second mortgage field (about which more later), this is an unfortunate omission, and it is interesting to note that the disclosure requirements in the American Consumer Credit Protection Act $^{44}$ extend to all real property

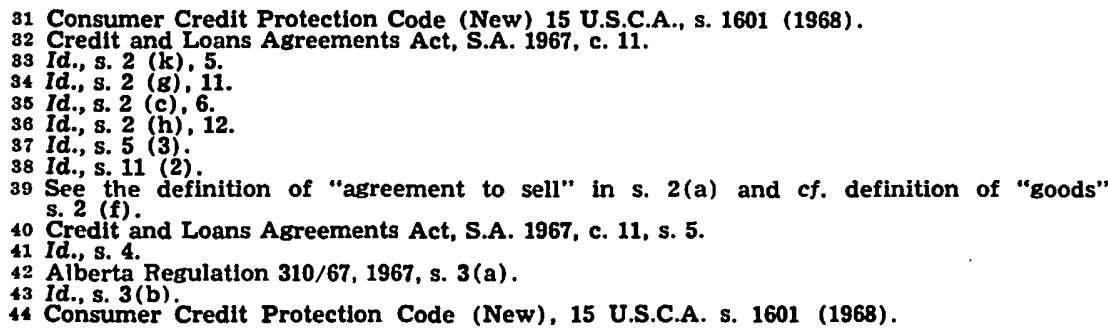


transactions for consumer purposes. ${ }^{45}$ There is no express exemption in the Alberta Act for bank loans, but the banks have taken the position that any attempt to apply the provincial disclosure legislation to them would be ultra vires. Since the introduction of comparable federal disclosure regulations, ${ }^{46}$ pursuant to s. 92 of the new Bank Act, ${ }^{47}$ the question has become largely academic.

As has been already indicated, the creditor is required to make a double disclosure of the cost of the credit or loan, namely, in terms of dollars and cents and as an effective annual percentage rate. The formula for calculating the true interest rate is prescribed in the regulations ${ }^{48}$ and is based on the ratio between the credit charge and the sum of the balance of the time price or the amount that the borrower will actually receive (as the case may be), the amounts charged separately at the debtor's request for physical damage and liability insurance or life, health and accident insurance, and on account of official fees. ${ }^{49}$ The exclusion of the last two items in the computation of the credit charge, and therefore from the conversion of the charge into an annual percentage rate, is ill-conceived. If the consumer were paying cash he would not incur these expenditures and therefore, it seems to this writer, they are part of the cost of buying on credit and should be treated as such.

Like the other Canadian Acts, the Alberta Act contains separate provisions concerning the disclosure of the percentage rate in open-ended credit agreements. The practice is for credit grantors to calculate the credit charge on the amount owing by the customer at the beginning or end of an accounting period without regard to payments that may have been made in the interval. The Act sanctions this practice, ${ }^{50}$ although, as will be appreciated, it does not give the true rate of interest. In the writer's opinion open-ended credit has now become so important that credit grantors should be required to calculate the credit charges on the daily balance rather than the monthly balance or some other period. With the aid of computers, the clerical work should not be oppressive. The author has found that many consumers have difficulty in understanding the basis on which department stores and other credit card issuers calculate their charges.

The penalties for non-compliance with the Act are surprisingly weak. The Act provides that the agreement shall not be void or unenforceable but that the creditor shall only be entitled to recover the cash selling price or actual amount of the loan received by the borrower, the insurance charges actually paid at the debtor's request, and such amount on account of the credit charge as the court "having regard to the purpose and intent of [the Act] considers just and proper in the circumstances." ${ }^{51}$ The offending creditor may also be fined $\$ 500$ if an individual, or $\$ 1,000$ if a corporation. ${ }^{52}$ The American Acts are generally more stringent and entitle the debtor, as of right,

\footnotetext{
45 Id., ss. $1602,1603,1631$.

18 S.O.R. 67, 504; The Canada Gazette, Part II, Vol. 101, p. 1586.

47 Banls Act, S.C. 1966-67, S. 92 (4).

18 Alberta Regulation 310/67, 1967, s. 8 (2).

49 Credit and Loans Agreements Áct, S.A. 1967, c. 11, ss. 5, 11.

50 Credit and Loans Agreements Act, S.A. 1967, c. 11, ss. 6. 12; Alberta Regulation 310/67, 1967, 8. 6 .

61 Credit and Loans Agreements Act, S.A. 1967, c. 11, ss. 9, 15

62 Id., 8. 24.
} 
to a remission of the finance charge as well as a fraction of the principal. The problem of securing the proper observance of consumer protection legislation is a recurring one. Many of the provinces have entrusted this function to a Consumer Protection Bureau or, as in Alberta's case, to a designated individual. ${ }^{53}$ Even so there is much to be said for the view that consumers should be given a personal incentive to help police an area of the law that is designed for their protection.

\section{Regulation of the Cost of Credit}

In a perfectly competitive economy it should not be necessary to have to regulate the cost of credit. It is this Benthamite philosophy that underlies section 2 of the federal Interest Act, ${ }^{54}$ which was first adopted in a preconfederation statute of 1858 repealing the various usury acts. ${ }^{55}$ However, the Canadian Parliament, like the British Parliament, soon discovered that laissez-faire theories do not apply to necessitous borrowers who are too ignorant or too weak to be able to protect their own interests effectively. This realization resulted in the adoption of a sucession of federal money-lenders' Acts and, finally, of the Small Loans Act of 1939. ${ }^{50}$.

However, this Act, in its amended form, only applies to loans up to $\$ 1,500 .^{5 T}$ The Porter Report ${ }^{58}$ and the Croll-Basford Report on Consumer Credit $^{50}$ urged the federal government to increase the ceiling to $\$ 5,000$, but these recommendations still await implementation. Had the federal government exercised its undoubted jurisdiction it is unlikely that many of the second mortgage abuses of which so much was heard in the fifties and sixties would have taken place. But in the absence of federal initiative, it was left to the provinces to bridge the gap and they did so in the form of an Act which usually travels under the intimidating title of Unconscionable Transactions Relief Act or, in Alberta's case, Unconscionable Transactions Act. ${ }^{60}$

The legislation is actually a borrowing from the English MoneyLenders Act of $1900 .^{61}$ Ontario adopted such an Act as early as 1912, ${ }^{62}$ but the other provincial acts are all of very recent origin. The constitutionality of the Ontario Act was upheld by the Supreme Court of Canada in A.G. Ontario v. Barfried Enterprises, Ltd.," ${ }^{63}$ although it should be noted that the Supreme Court expressed no opinion as to what would have been the position if there had been conflicting federal legislation. Time does not permit an examination of the Canadian legislation in any depth, but perhaps the following brief observations may be useful.

Most of the provincial Acts, like the Alberta Act, only apply to loan transactions, whether or not the loan is secured. However, several of the provincial Acts also cover other credit transactions such as credit

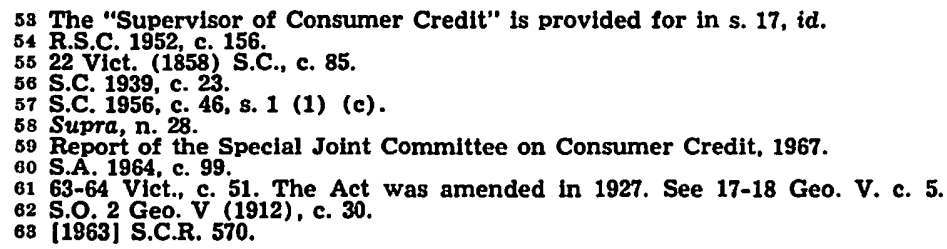


sales. This seems only logical. If it is correct to say that the federal government lacks jurisdiction to regulate finance charges in non-loan transactions, because such charges do not technically amount to "interest", then only the provinces can prevent unconscionable rate practices in this area.

The Alberta Act entitles the court to reopen a money lending transaction if, in the court's opinion, the cost of the loan is excessive and the transaction is harsh and unconscionable. The double test was intentionally adopted in the British Act because the Select Committee of the House of Commons which recommended the legislation envisaged situations in which a borrower might freely agree to pay an exorbitant price for the privilege of obtaining the loan. In such circumstances the committee did not feel he was entitled to relief. The judgment of Judge Sweet in the Ontario case of Morehouse v. Income Investments $L t d .^{64}$ enumerates a number of factors which are relevant in deciding whether or not there is present the element of unconscionability. In practice, however, the few reported Canadian decisions have only paid lip service to the double test: once it is shown that the cost of the loan was excessive the courts appear to be willing to assume that it was also unconscionable, at least until the contrary is shown. At least one province, Saskatchewan, has omitted the double test and under its Act it is only necessary to show that the cost of the loan is excessive or that the transaction is harsh and unconscionable. ${ }^{.5}$

What is the meaning of "excessive"? Here again there appears to be an interesting divergence between British and Canadian practice. The British courts appear to be rather tolerant and rates of $60 \%$ or more have been upheld. The few reported Canadian cases, on the other hand, seem to leave very little margin between prevailing rates for a loan of a similar character and what is regarded as an excessive rate. It may be that the difference is more apparent than real. The British consumer loan market is much less well developed than the Canadian market, and it may be that the British courts lack the guidance of reasonably well established prevailing rates.

My own opinion is that the parties should not have to litigate in order to determine what is a usurious rate. As the Small Loans Act shows, it is perfectly feasible for Parliament to set a range of ceilings for loans of various levels, and there seems to be no reason why the same could not be done for consumer loans above $\$ 1,500$. Most American state acts do so, and the Uniform Consumer Credit Code does so for consumer loans up to $\$ 25,000 .^{\text {i6 }}$

Two related problems also deserve some mention. The first concerns the use of "balloon" clauses in loan agreements and the second involves the position of assignees of loan agreements that are attacked on the grounds of unconscionability. As for balloon clauses, the Ontario Select Committee was opposed to prohibiting their use but recommended that the lender should be required to draw attention to the presence of the clause in ink of a different colour. The author much prefers the approach adopted in UCCC 3.402. ${ }^{67}$ This provides that:

64 (1965) 53 D.L.R. (2d) 105

65 Unconscionable Transactions Relief Act S.S. 1967, c. 86, s. 3

G6 Supra, n. 18, ss. 3.104, 3.508.

o7 Supra, n. 18. 
"With respect to a consumer loan, other than one primarily for an agricultural purpose or one pursuant to a revolving loan account, if any scheduled payment is more than twice as large as the average of earlier scheduled payments, the debtor has the right to refinance the amount of that payment at the time it is due without penalty. The terms of refinancing shall be no less favorable to the debtor than the terms of the original loan. These provisions do not apply to the extent that the payment schedule is adjusted to the seasonal or irregular income of the debtor."

The problem of assignees is analogous to the problem involving the use of promissory notes and cut-off clauses in chattel paper which will be discussed in the next section. One would therefore expect that similar solutions would be applied. So far this has not happened. Many of the provincial Unconscionable Transactions Acts have borrowed the provision in the English Money-Lenders Act to the effect that nothing in the Act shall affect the rights of a bona fide assignee or holder for value without notice. ${ }^{68}$ This leaves the borrower rather empty handed if the lender has disappeared or, in the case of a company, has been wound up or has become insolvent.

Nova Scotia and Saskatchewan have adopted a compromise solution. Their Acts provide that where the assignment takes place within two years following the original transaction the assignee shall be deemed to have notice of every particular and all circumstances surrounding the loan unless the debtor has made an acknowledgement in writing of the amount of the loan and of the particulars. ${ }^{69}$ The acknowledgement must be made before an independent solicitor not earlier than fortyeight hours after the money lent has been disbursed or the credit granted has been wholly extended. Presumably the effect of an acknowledgement is to prevent the debtor from contradicting the facts stated in them.

\section{Promissory Notes and Cut-off Clauses}

As previously indicated, few retailers carry their own paper and they usually discount it with a finance company or, occasionally, with one of the chartered banks. For understandable though not always creditable reasons the assignee wants to be sure that he has a good claim and that he will not become involved in disputes between the seller and the buyer concerning the quality of the goods or any other aspect of the original transaction. If he simply had to rely on the common law position he would not secure this measure of isolation since the common law rule is that the assignee of a chose in action takes it subject to all equities. To overcome this obstacle finance companies regularly resort to the following three devices:

(a) They ensure that there is a disclaimer clause in the sales contract which excludes all implied warranties and conditions and all representations not incorporated in the written contract;

(b) They also ensure that the contract contains a "cut-off" clause. This clause notifies the buyer of the seller's intention to assign the contract and the buyer purports to agree that he will not raise any defences or other equities against any assignee of the paper;

68 Moneylenders Act, 1927; 17-18 Geo. V, c. 21, s. 17.

69 Unconscionable Transactions Relief Act, R.S.N.S. 1967, c. 319, s. 6; Unconscionable Transactions Relief Act, S.S. 1967, c. 86, s. 7. 
(c) Finally, the buyer is required to sign a promissory note for the balance of the time sale price, and this is negotiated by the dealer to the finance company. In this way the finance company hopes to acquire the superior status of a holder in due course under section 56 of the Bills of Exchange Act. ${ }^{70}$

The general question of disclaimer clauses will not be dealt with here $^{i 1}$ and I will therefore proceed immediately to the two other devices. Until the decision of the Supreme Court of Canada in Killoran v. Monticello State Banki2 there was considerable doubt in Canada about the effect of cut-off clauses in conditional sale agreements and the status of a promissory note which formed a physical part of the agreement and was separated from it only by a perforated edge. However, the Supreme Court dispelled the doubts and each of the devices received the blessing of a majority of the judges. No questions were raised in the case concerning the effect of a close relationship between the assignor and assignee, such as today typically exists between the dealer and his finance company, and having regard to the early date of the decision it would have been surprising if the question had been raised.

Until 1962, Killoran v. Monticello State Bank $k^{73}$ constituted the finance company's talisman and rare indeed was the case in which the consumer succeeded in denying the company's holder in due course status. In that year, in a now seminal decision, Federal Discount Corp. v. St. Pierre, ${ }^{74} \mathrm{Mr}$. Justice Kelly of the Ontario Court of Appeal, on appeal from a decision of a county court judge, denied a finance company a holder in due course status because of its close links with the seller and its familiarity with the seller's modus operandi. The learned judge apparently rested his decision partly on the theory of a joint venture and partly on the grounds that the Bills of Exchange Act was "merchants' law" and was never designed to invade the sphere of consumer transactions. Curiously he did not attempt to distinguish Killoran's case; in fact he did not even refer to it. One does not have to be a very profound scholar to realize that the judge was basically trying to restore a little equity into an area that has spawned many abuses.

The trial courts in the other provinces quickly welcomed $\mathrm{Mr}$. Justice Kelly's judicial initiative. The appeal courts were a little more reserved. In Prudential Finance Corporation v. Kucheran, ${ }^{75} \mathrm{Mr}$. Justice Schroeder distinguished the St. Pierre case and said that it turned on its "peculiar facts". It was also distinguished by the Alberta Appellate Division in Trading Finance Corp. v. Edmonton Airport Hotel Co. Ltd. ${ }^{70}$ on the grounds that there was no close relationship between the finance company and the endorser of the note as there had been in the St. Pierre case. In two recent decisions a majority of the Quebec Appeal Court has not even bothered to distinguish Mr. Justice Kelly's decision but

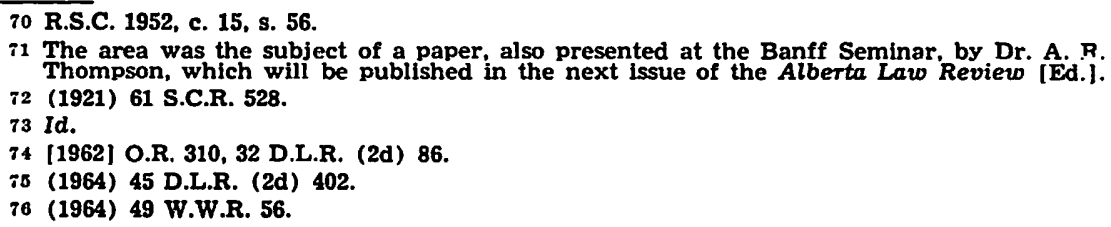


has attempted to consign it into limbo by the simple expedient of ignoring it. $^{77}$

The Range ${ }^{i 8}$ case was appealed to the Supreme Court of Canada and the court's decision was rendered in a still unreported judgment on the 17th of February of this year. ${ }^{79}$ Many must have hoped that the court would at least indicate its reaction to the Kelly doctrine. No such luck! The unanimous judgment of the court written by $\mathrm{Mr}$. Justice Pigeon does not even refer to it. Instead the Supreme Court decided the appeal on grounds that will prove even more distressing to the financial community than the Kelly doctrine. The court held that a promise to pay which appears on the same sheet of paper as a conditional sale agreement, even if separated from it by a perforated edge, is not technically a promissory note but forms part of the overall agreement. As a result the finance company was denied the status of a holder in due course.

Surely, it wil be said, this flies in the face of the court's own decision in Killoran's case and the understanding of the legal profession for almost fifty years. Mr. Justice Pigeon viewed the earlier decision differently. He said it merely decided the effect of a cut-off clause and then went on to explain that in the agreement before the court there was no such clause.

What all this means, is that the Canadian law of consumer notes is in a state of sorry confusion. What should be done about it? In the admittedly biased opinion of the author, the solution is to amend the Bills of Exchange Act to require all notes given in connection with consumer credit transactions to be marked Consumer Note and to provide that any holder of such a note shall take it subject to all the equities that the consumer would have been entitled to raise in an action by the payee of the note. There is nothing novel about this approach. It was proposed in the Croll-Basford Report, and it has a respectable precedent in sections 14-16 of the Bills of Exchange Act.8 A substantial number of American states have gone even furtherthey prohibit altogether the taking of negotiable consumer notes, but this perhaps goes unnecessarily far. An alternative solution which has been adopted in a number of American states is to require the endorsee to inform the consumer of the negotiation of the note to him and then to allow the consumer a limited period in which to notify the holder of any defences he has. You may recall that Nova Scotia and Saskatchewan have adopted a not dissimilar solution with respect to the assignment of loan contracts. The Uniform Consumer Credit Code has adopted both solutions as suitable alternatives.

It is generally assumed that the federal government has no jurisdiction over cut-off clauses and that their use will have to be regulated by the provinces. ${ }^{81}$ Manitoba in effect proscribes their use, as does also

i) Sèe Corporation de Finance Belvedere v. Range [1967] Que. Q.B. 932, and Imperial Oil Ltd. v. Fortier [1968] Que. Q.B. 315.

78 [1967] Que. Q.B. 932.

70 The case has now been reported. See [1969] S.C.R. 492, 5 D.L.R. (3d) 257.

80 Bills of Exchange Act, R.S.C. 1952, c. 15, ss. 14-16.

81 The assumption is open to question. Some American courts have held that cut-off clauses constitute an improper attempt to confer a negotiable character on chattel paper by means nnt in accordance with their nesotiable instrument laws. If section 91 (18) of the B.N.A. Act is construed as conferring a general jurisdiction over negotiable instruments on the federal government, and the American characterization is adopted, then the federal government could regulate the use of cut-off clauses. 
the Uniform Consumer Credit Code. This would seem to be the correct approach. Once it is accepted that the typical consumer does not understand what he so readily signs and would not be able to change the agreement if he did, the need to protect him appears obvious. Contrary to the claim that is sometimes made, these regulatory measures will not spell the end of the consumer credit industry. The finance company that deals with reputable dealers has little to fear and has an adequate dealer's reserve fund out of which to recoup the occasional loss or to charge back a contested debt. The proposed measures will make finance companies a little more careful in buying paper from a questionable source and that, surely, would be all to the good.

\section{Restrictions on the Creditor's Remedies and Relief for the Overcommitted Debtor}

If a debtor defaults in his payments the creditor's remedies will vary depending on whether or not the debt is secured. If the debt is secured then, in the absence of statutory restrictions, the creditor can enforce his security or sue for the debt or do both. If there is no security the creditor is restricted to his personal remedies.

Until very recently almost all of the provincial legislation focused on the secured seller's real remedies, and even that was of a fairly nominal character. Most of the conditional sales acts copied the provisions in the Uniform Conditional Sales Act conferring an equity of redemption on the buyer and requiring the seller to notify the buyer of his intention to repossess the goods and to hold the buyer liable if there was a deficiency after the goods had been resold. The Alberta and Saskatchewan legislation went considerably further. As early as 1929 Alberta entitled a buyer to object to a seizure by his seller and empowered a court to stay further repossession proceedings on such terms as the court saw fit. ${ }^{82}$ In 1942 the Conditional Sales Act was amended with a view to requiring the seller to elect between repossessing the goods and suing for the price.83 Saskatchewan does not even permit this election and since 1933 the seller has been limited to his right to repossess the goods. ${ }^{84}$

The prairie legislation was adopted, partly in response to depression conditions and partly because it was felt unfair that the seller should be able to repossess the goods and still hold the buyer responsible for the price. It has often been objected, and with some justice, that the restrictions are arbitrary and that they punish the careful creditor as well as the creditor who has granted credit recklessly. The fact remains that an increasing number of provinces are becoming concerned about the incidence of overcommitted debtors and the harsh collection tactics that have been employed by some creditors.

This concern manifests itself at two levels. First, three provincesQuebec, Manitoba, and Newfoundland-have now also adopted the Alberta election of remedies principle, and several others, including Nova Scotia and Ontario, have introduced a provision requiring a creditor to obtain a court order before permitting him to repossess the goods 
where two-thirds or more of the price has been paid. There is a comparable restriction in the British Hire-Purchase Act, ${ }^{85}$ with the difference that the dividing line is one-third or more of the price. This would appear to be a more realistic figure if the buyer's equity in the goods is to be effectively protected.

The second type of reaction involves new restrictions on the creditor's personal remedies. The most valuable asset of many consumers-indeed often their only valuable asset-is their weekly pay check. The garnishment of salaries to enforce payment of consumer credit debts is commonplace, and some creditors also resort to wage assignments. It has been found that both these devices create havoc with the debtor's personal security. Employers strongly object to being required to act as collection agents and often threaten to dismiss an employee whose wages have been garnisheed more than once. Even if dismissal does not result, after garnishment the worker usually is not left with enough money to support himself and his family at even a modest level. These well documented facts are causing the provinces to take a new look at their garnishment and wage assignment laws. Last year Ontario outlawed wage assignments altogether, save where the assignment is made in favour of a credit union. ${ }^{86}$ American commentators have strongly argued that wage garnishments to enforce consumer credit debts should also be proscribed, but so far very few American states and none of the Canadian provinces have taken this radical step. Merely increasing the amount exempt from attachment may not be enough since the basic needs of no two families are exactly alike. The Ontario Wages Act ${ }^{87}$ entitles the debtor to apply to the court for an order exempting his earnings from attachment in whole or in part, and this provides a more flexible solution. The best solution however would be to require a court hearing in all cases before a creditor is authorized to attach his debtor's earnings.

Limiting the creditor's real and personal remedies may offer the debtor some relief, but it does not provide a permanent solution to the consumer who is harassed by many creditors. The number of such Canadians is unfortunately substantial. Referring again to the Hamilton survey, ${ }^{88}$ it was found that $25 \%$ of the families owed $\$ 500$ or more in consumer debts and that their indebtedness represented $30 \%$ or more of their annual income. According to the Hamilton Credit Bureau records, $14.8 \%$ of the families were classified as poor credit risks.

Three solutions are currently available in Canada for the consumer who finds himself burdened with too many debts. He may resort to the services of a voluntary consumer credit counselling agency; he may file an application under Part $\mathrm{X}$ of the federal Bankruptcy Act; or he may simply go bankrupt. Each of these possibilities has serious drawbacks. Very few Canadian cities have full time and adequately staffed credit counselling agencies and still fewer are in a position to offer free prorating services. Part X of the Bankruptcy Act ${ }^{89}$ is at present only in force in Alberta, Manitoba, Saskatchewan and Prince

85 Hire-Purchase Act, 1964, c. 53.

86 The Wages Amendment Act 1968, S.O. 1968, c. 142

87 R.S.O. 1960 , c. 421 .

88 Supra, n. 19.

80 R.S.C. 1952, c. 14. 
Edward Island, and it also suffers from other limitations. It only applies to individual debts up to a maximum of $\$ 1,000$ (unless the creditor agrees to waive the limitation) and does not apply at all to secured debts. More serious still, the clerk of the court who administers the scheme has no power to discharge the debtor's liabilities even though there is no prospect of the debtor being able to meet them within a reasonable period of time; at best the clerk can only make an order absolving the debtor from the need to make payments into court.

The hopelessly insolvent consumer would appear to be a ripe case for bankruptcy, but here too he is faced with the formidable hurdle of high trustees' fees-anything from $\$ 300$ to $\$ 500$-and an Act which was never designed for the mass consumption debtor oriented society in which we now live. The Credit Counselling Services of Metropolitan Toronto has suggested the appointment of publicly paid trustees in bankruptcy, but this suggestion still awaits implementation. This author suggests that the personal bankruptcy provisions in the Bankruptcy Act should be integrated with those in Part X and that the clerk of the court should be able to combine his normal functions with those of a trustee in bankruptcy. Most bankrupt consumers have very few assets apart from their wage and the detailed provisions of the Bankruptcy Act are quite unsuited to their needs.

This article began by citing some impressive figures about the growth of consumer credit in Canada. It has ended on the salubrious note of bankruptcies. Perhaps the moral is that there is not always a pot of gold at the end of the consumer credit rainbow. ${ }^{90}$

90 For a more detailed examination of many of the questions touched on in this paper, see Ziegel, "Consumer Credit Regulation: A Canadian Consumer Oriented Viewpoint" (1968) 68 Col. L. Rev. 488. 